\title{
Communicative Approach and Teaching of Spoken English in College
}

\begin{abstract}
SHI Xi-chun, CHEN Meng-jie
Changchun University, Changchun, China

Communicative Approach created in the early 1970s. In just 10 years, it is accepted by English teachers, and played a leading role in English teaching. After being introduced into China, communicative approach also has been widely popular, especially its great function in college oral English teaching. This paper sets forth the theoretical basis of communicative approach through the eyes of history, puts forward the three principles to follow when using communicative approach in college oral English teaching, and comes up with the three pairs of main relations in the process of teaching.
\end{abstract}

Keywords: Communicative Approach, college English, oral English teaching

\section{Introduction}

Communicative Approach is a kind of teaching method with language function projecting and emphasizing on communication ability, whose purpose is to improve the language learners' communicative competence, and make further development of the four skills in language learning: listening, speaking, reading, and writing. According to the new "college English curriculum requirements", the purpose of college English teaching is to cultivate the students' English comprehensive application ability, especially listening and speaking skills, so that the students can write and communicate in English effectively. While the communicative approach is an effective method of college English teaching satisfying the requirements of new curriculum, especially in promoting the college spoken English teaching level, and improving the students' oral English using ability.

\section{Linguistics Theories Base of Communicative Approach}

\section{Hymes's Theory of Communicative Competence}

Hymes published a article titled Theory of Communicative Competence in 1972, in which he proposed communicative competence consisting of four parts: (1) whether possible in the form; (2) whether possible to perform; (3) whether appropriate according to the context; and (4) whether can be achieved in fact. This four parts include the abilities of language and grammar, as well as the feasibility and appropriateness. His theory of communicative competence provides a theoretical basis for the later of communicative approach in English teaching.

SHI Xi-chun, lecturer, master, Public Foreign Language Teaching and Research Department, Changchun University. CHEN Meng-jie, lecturer, master, Public Foreign Language Teaching and Research Department, Changchun University. 


\section{Canale and Swain's Theory of Communicative Competence}

In the early 1980s, Canal and Swain's theory of communicative competence enriches Hymes's theory of communicative competence. They think that communication skills include: grammar, social language, discourse, and strategic competence. Practice proved their communicative competence theory programmatic and guiding standards to guide language teaching and the test framework.

\section{Bachman's Theory About Communicative Language Ability}

In the early 20th century, Bachman put forward the theory of communicative language ability on the basis of various theories. He thought the communicative language ability was composed of three parts, namely, language ability, strategy ability, and psychological mechanism ability. He made it systematic, and finally included psychological mechanism in the communicative language ability. In addition to enriching the language ability in communicative competence, Bachman also dealt with the strategy ability as a part of a language independent ability, indicating the implementation of the relative importance of factors.

\section{Two Basic Principles to Follow for Communicative Approach in Oral English Teaching}

\section{Oral English Teaching Activities Should Centre on Communication}

The first principle to follow for communicative approach is that the organization and implement of the oral English teaching activities should center on and serve for communicative purpose in class. Oral English activities implemented by teachers and students in college oral English teaching can be mainly divided into direct and indirect communication activity, and the later serves for communicative activities. The presentation of the direct communication activities is the simple oral training between teachers and students before class, such as asking students the weather and their weekend, etc. While indirect oral teaching serving for the communication activities is study and practice of some phrases or sentences under the guidance of teachers, which will lay a foundation for students in the future learning.

\section{Do Not Always Correcting Students' Mistakes in Class}

Communicative Approach pays attention to the communication of meaning in the classroom communicative teaching, and free choice of language, rather than focusing on the accuracy of language. It is usual for students to make mistakes when using language in the process of communication, but the approach of "mistakes must be corrected" can make students dare not express their bold because of afraid of making mistakes, which eventually hinders students free communication.

\section{Three Major Relationships of Communicative Approach in Oral English Teaching}

\section{The Relationship Between Teachers and Students}

Traditional English teaching mainly focuses on teaching language knowledge ignoring the oral English exercise for students, thus the teachers' teaching plays the subject of the classroom. While students are passive listeners, the only thing students can do is listening and note-taking. But communicative approach emphasizes the enhancement of students' oral English ability. So teachers and students should change their roles in the teaching process. As a teacher, he must change a classroom organizer from knowledge teaching. While as a student, he must be from a passive listener to an active participant, as well as the subject of teaching activities and feedback of teaching information. In a word, the implementation of communicative approach in oral English teaching is the 
process of relying on, helping, and promoting each other between teachers and students.

\section{Accuracy and Fluency}

Compared with communicative approach, traditional teaching method relatively focuses on the accuracy of the language. And in traditional teaching process, teachers constantly monitor the students' language accuracy and help students to correct immediately when meeting students' mistakes in oral English. So for a long time, this method will make students have scruples, even each student will first consider themselves before speaking, and then express it instead of blurting out. As a result, too much emphasis on language fluency will prevent the natural use of language. Only by fully using the language to complete the communication between each other, can it be named true communication. Therefore, communicative approach in college oral English teaching should deal well with the relationship between the students' language accuracy and fluency. Students should achieve the accuracy of the language using through certain language knowledge learning on the basis of language fluency.

\section{Learn and Acquisition}

Canale (1983), an American linguist, thinks that there are two obvious ways to the development of language skills, namely learning and acquisition. Learning refers to the conscious acquirements of language knowledge, learning and understanding rules of grammar and language, and being able to talk about these rules. While acquisition means gaining natural language ability through the understanding and use of language under the way of nature. College oral English teaching is different from other teaching, such as grammar and reading. Students can learn to master some language knowledge, but it does not mean students have the ability of expressing the language knowledge in oral English fluently. The improvement of oral English greatly relies on a certain language environment, as well as a long-term practice in language environment, such as making students obtain more language input through dialogue communication between teachers and students in the class or taking part in English corner, and encouraging students' language acquisition in the subconscious.

\section{Some Suggested Classroom Activities}

\section{Role-Play}

There is little consensus about the term, "role-play". Richards, et al said that it is a drama-like activity,

In which students take the roles of different participants in a situation and act out what might typically happen in that situation. For example, to practice how to express complaints and apologies in a foreign language, students might have to role-play a situation in which a customer in a shop returns a faulty article to a salesperson. (Richards, J. Platt, \& H. Platt, 2002, p. 398)

As to the limitations of the classroom, role-play now is a vital technique for creating a wider variety of social situations and relationships that would otherwise occur. A role-play is a highly flexible learning activity which has a wide scope for variation and imagination. Role playing can improve students' oral skill in any circumstance, and help students interact with others. As for introverted students, role-play can provide a mask, which can make them feel safe and act freely.

\section{Oral Presentation}

Generally speaking, oral presentation falls into two categories: (1) a prepared presentation; and (2) an impromptu presentation. As to the first kind, the students can have plenty of time to prepare for it. They can 
consult different materials and rehearse what they are going to talk about, even with some key words written on a piece of paper just in case of stage fright. This prepared speech should be encouraged since it helps to improve accuracy, and quality of the presentation in terms of content. In contrast, the impromptu presentation is far more difficult because the student has no time to prepare and no input from other group members. Teachers should use it with care, depending on the proficiency level of our students. If the general level of the students is low, it should not be used too often as it has the potential to damage students' self-esteem and can be demoralizing if not done properly.

The topic of the presentation can be given by the teacher, but it is more favorable if chosen by the speaker himself. He can choose some hot topics in social life, or English jokes, some anecdotes, news, etc. And it is often effective to get the candidate to talk about himself, such as dreams, hobbies, private life, etc.

\section{Discussion}

Discussion is probably the most commonly used activity in the oral skill class. Typically, students are introduced to a topic via a reading, a listening passage, or a videotape and are then asked to get into pairs or groups to discuss a related topic in order to come up with a solution, a response, or the like. Otherwise teachers can choose a topic that is related to the content of the following reading class. They must take care in planning and setting up a discussion activity. Firstly, planned (versus random) grouping or pairing of students may be necessary to ensure a satisfactory discussion outcome. While there is no one "right way" to group students, considerations such as gender, ethnicity, background, talkativeness, etc., may come into play. Secondly, students need to be reminded that each person should have a specific contribution in the discussion, whether it is to keep time, take notes, or report results. Lastly, students need to be clear about what they are to discuss, why they are discussing it, and what outcome is expected. It is testified that students will be more motivated to participate in the discussion if they are allowed to select discussion topics and evaluate their peers' performance.

\section{Games}

Communication games are based on the information-gap principle. Students are put into situation which are "game-like" and have to use the limits of the language they possess to complete the game. Three examples are offered in the following:

(1) Describe and arrange: Students work in pairs. One partner has to describe a pre-arranged set of pictures, while the other is required to arrange identical individual pictures in the same order. The pictures of both participants are unnumbered, thus provoking true communication, not only to find a particular picture, but also to locate it;

(2) Describe and draw: Once again students work in pairs. One student has a picture which the other student cannot see. The second student has to draw an identical picture by listening to his partner's instructions and/or asking for questions;

(3) Find the similarities: Students are put into pairs and given two pictures which are different but which contain a number of similarities. Without looking at each other's pictures, they must discover what the similarities are.

\section{Conclusion}

Communicative approach is an effective method of teaching English, though there are still some problems in 
the use of Chinese, with the development of teaching conditions, we are sure that this method can be widely into our classroom, especially in college English teaching in the classroom, and will become a kind of effective teaching methods improving students' other English skills in addition to oral English ability.

\section{References}

Bachman, L. F (1990). Fundamental considerations in language testing. New York: Oxford University Press.

Canale, M. (1983). From communicative competence to communicative language pedagogy. In J. C. Richards and R. W. Schmidt (Eds.), Language and communication (pp. 2-27). London: Longman.

Canale, M., \& Swain, M. (1980). Theoretical bases of communicative approaches to second language teaching and testing. Applied Linguistics, 1, 1-41.

Richards, J. C., Platt, J., \& Platt, H. (2002). Longman dictionary of language teaching and applied linguistics (pp. 147-149). Beijing: Foreign Language Teaching and Research Press.

Savignon, S. J. (1983). Communicative competence: Theory and classroom practice. MA: Addison-Wesley Publishing Company. Widdowson, H.G. (1978). Teaching English as communication. Oxford: Oxford University Press.

$\mathrm{XU}$, Q. (2002). Communicative approach and examination evaluation in English teaching. Shanghai: Shanghai Teaching and Research Press.

XUE, Z. L. (2002). English classroom teaching process. Beijing: People's Education Press. 